\title{
OPEN Diagnostic accuracy of the different hormonal tests used for the diagnosis of autonomous cortisol secretion
}

\author{
Marta Araujo-Castro ${ }^{1,4,5 凶}$, Ana García Cano², Lucía Jiménez Mendiguchía ${ }^{2}$, \\ Héctor F. Escobar-Morreale ${ }^{3,4,5,6}$ \& Pablo Valderrábano ${ }^{3,5}$
}

To evaluate the diagnostic accuracy of the different tests commonly used in the evaluation of adrenal incidentalomas (Als) for the identification of autonomous cortisol secretion (ACS) and comorbidities potentially related to ACS. In a retrospective study of patients with Als $\geq 1 \mathrm{~cm}$, we evaluated the diagnostic reliability and validity of the dexamethasone suppression test (DST), urinary free cortisol (UFC), ACTH, late-night salivary cortisol (LNSC), and dehydroepiandrosterone-sulphate (DHEAS) for the diagnosis of comorbidities potentially related to ACS. Diagnostic indexes were also calculated for UFC, ACTH, LNSC, and DHEAS considering DST as the gold standard test for the diagnosis of ACS, using three different post-DST cortisol thresholds $(138 \mathrm{nmol} / \mathrm{L}, 50 \mathrm{nmol} / \mathrm{L}$ and $83 \mathrm{nmol} / \mathrm{L})$. We included 197 patients with Als in whom the results of the five tests abovementioned were available. At diagnosis, $85.9 \%$ of patients with one or more Als had any comorbidity potentially related to ACS, whereas $9.6 \%$ had ACS as defined by post-DST cortisol $>138 \mathrm{nmol} / \mathrm{L}$. The reliability of UFC, ACTH, LNSC, and DHEAS for the diagnosis of ACS was low (kappa index $<0.30$ ). Of them, LNSC reached the highest diagnosis accuracy for ACS identification (AUC $=0.696[95 \% \mathrm{Cl} 0.626-0.759])$. The diagnostic performances of these tests for comorbidities potentially related to ACS was poor; of them, the DST was the most accurate (AUC $=0.661[95 \% \mathrm{Cl} 0.546-0.778]$ ) and had the strongest association with these comorbidities (OR 2.6, $P=0.045)$. Patients presenting with increased values of both DST and LNSC had the strongest association with hypertension (OR 7.1, $P=0.002)$ and with cardiovascular events (OR 3.6, $P=0.041$ ). In conclusion, LNSC was the test showing the highest diagnosis accuracy for the identification of ACS when a positive DST was used as the gold standard for its diagnosis. The DST test showed the strongest association with comorbidities potentially related to ACS. The definition of ACS based on the combination of elevated DST and LNSC levels improved the identification of patients with increased cardiometabolic risk.

Adrenal incidentalomas (AIs) are defined as adrenal masses detected in imaging tests performed for reasons unrelated to adrenal disease $\mathrm{e}^{1-3}$. All patients with AIs must be evaluated to exclude malignancy and hormonal excess ${ }^{4,5}$. Even though imaging tests offer a high sensitivity and a reasonable specificity for the diagnosis of malignancy, functional evaluation of AIs is often challenging. Particularly, consensus is lacking regarding the definition and diagnostic criteria of autonomous cortisol secretion (ACS), which may associate an increased cardiometabolic morbidity and mortality and might appear in as many as $20 \%$ of patients with AIs $^{6}$. Nonetheless, ACS is usually defined by an incomplete cortisol suppression in response to the overnight $1 \mathrm{mg}$ dexamethasone suppression test (DST), in the absence of clinical data specific of Cushing's syndrome ${ }^{4,5,7,8}$. Nevertheless, other tests such as 24-h urinary free cortisol (UFC), late-night salivary cortisol (LNSC) and plasma adrenocorticotropic hormone (ACTH) have been proposed for the definition of ACS. However, there are few data comparing these tests and the DST for the diagnosis of ACS; hence, UFC, LNSC and ACTH are usually used as tools to complement the results

\footnotetext{
${ }^{1}$ Neuroendocrinology Unit, Department of Endocrinology \& Nutrition, Hospital Universitario Ramón y Cajal, Madrid, Spain. ${ }^{2}$ Department of Biochemistry, Hospital Universitario Ramón y Cajal, Madrid, Spain. ${ }^{3}$ Department of Endocrinology \& Nutrition, Hospital Universitario Ramón y Cajal, Madrid, Spain. ${ }^{4}$ Universidad de Alcalá, Madrid, Spain. ${ }^{5}$ Instituto Ramón y Cajal de Investigación Sanitaria (IRYCIS), Madrid, Spain. ${ }^{6}$ Centro de Investigación Biomédica en Red Diabetes y Enfermedades Metabólicas Asociadas (CIBAERDEM), Madrid, Spain. ${ }^{\square}$ email: marta.araujo@salud.madrid.org
} 


\section{Patients with adrenal incidentalomas \\ evaluated with DST between 2013-2020 at \\ our institution $(n=730)$}

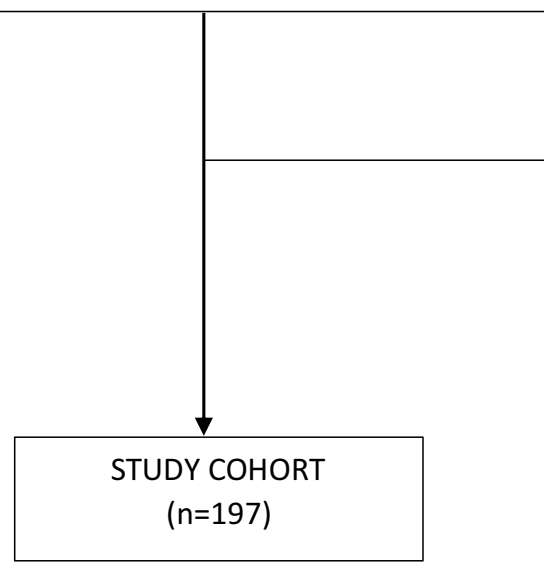

\author{
EXCLUSION CRITERIA: \\ -Adrenal carcinoma ( $n=2)$ \\ -Primary aldosteronism $(n=12)$ \\ -Pheochromocytoma $(n=4)$ \\ -Overt Cushing's syndrome $(n=2)$ \\ -Adrenal metastasis ( $n=1)$ \\ -Missing information in DHEAS \\ ( $n=269)$, ACTH $(n=222)$, LNSC $(n=364)$ \\ or UFC $(n=354)$
}

Figure 1. Study cohort. DST dexamethasone suppression test, LNSC late-night salivary cortisol, UFC urinary free cortisol.

of the DST in this setting. On the other hand, under usual routine clinical practice conditions, the diagnostic performance of the DST and complementary tests for the identification of comorbidities potentially related to ACS seems to be poor.

We hypothesized that the identification of cardiometabolic morbidities potentially related to ACS in patients with AIs could improve with the use of a panel of tests usually used to characterize adrenal function, either individually or in combination. Moreover, we evaluated the reliability and validity for the diagnosis of ACSconsidering an increased DST result as the gold standard for ACS definition following current European clinical guidelines ${ }^{2}$ - of four tests routinely used for the evaluation of adrenal function, including plasma ACTH, age and sex adjusted serum dehydroepiandrosterone sulphate (DHEA-S) levels, UFC and LNSC.

\section{Methods}

Patients. We retrospectively queried the electronic registry of the hormone laboratory of Hospital Universitario Ramón y Cajal to identify all patients in whom a DST had been performed between 2013 and 2020. We reviewed their medical records and selected those patients aged 18 to 90 years-old who presented with incidentally discovered unilateral and/or bilateral AIs of at least $10 \mathrm{~mm}$ in the largest diameter. We excluded patients with: (i) known diagnosis of hereditary syndromes associated with adrenal tumours; (ii) chronic treatment with glucocorticoids or drugs that might affect dexamethasone metabolism; (iii) treatment with oral hormonal contraceptives during the 6 weeks preceding the test; (iv) AIs identified during the extension study of an extraadrenal cancer; (v) patients with overt syndromes of adrenal hormone excess, (vi) adrenocortical carcinoma; (vii) adrenal metastasis from extra-adrenal tumours; and (viii) missing information in the results of one or more of the five tests evaluated here) (Fig. 1). We analysed patients' data obtained during their initial evaluation and at their last available follow-up visit.

Clinical evaluation. Demographics information such as age and sex; presence of comorbidities potentially related to ACS (hypertension, type 2 diabetes, obesity, dyslipidaemia, cerebrovascular and cardiovascular disease); body mass index (BMI); and systolic and diastolic blood pressure were extracted from medical records. Obesity was defined by a BMI equal or greater to $30 \mathrm{~kg} / \mathrm{m}^{2}$. Hypertension was defined as systolic blood pressure equal to or greater than $140 \mathrm{mmHg}$ and/or diastolic blood pressure equal to or greater than $90 \mathrm{mmHg}$, or treatment with blood pressure lowering medications. Diagnosis of type 2 diabetes and dyslipidaemia was based on current standards $\mathrm{s}^{9,10}$. Cardiovascular disease was defined as ischemic heart disease or heart failure, and cerebrovascular disease as transient ischemic attack or acute stroke.

Management decision regarding AIs-either observation or surgery-after the last follow-up visit was also registered.

Biochemical and hormonal evaluation. Routine biochemical profile after an $8 \mathrm{~h}$ overnight fasting was performed at diagnosis and at the last follow-up visit available. Biochemical profiles included fasting plasma glucose, total cholesterol, LDL-cholesterol, HDL-cholesterol, triglycerides and HbA1c (the latter was available only in 55 cases). Hormonal studies at the initial evaluation included urinary catecholamines and/or urinary metanephrines, DST, UFC, ACTH, DHEA-S and LNSC.

DST, UFC, ACTH, age- and sex-adjusted DHEA-S, and LNSC were analysed as continuous and categorical variables. When considering the DST test as the gold standard for the calculation of reliability and validity for ACS diagnosis of the others tests of adrenal function, we evaluated not only the post-DST cortisol $138 \mathrm{nmol} / \mathrm{L}$ 


\begin{tabular}{|l|l|l|l|}
\hline Age & Female $(\mathbf{n g} / \mathbf{m L})$ & Age & Males $(\mathbf{n g} / \mathbf{m L})$ \\
\hline $18-24$ & $150-3402$ & $20-29$ & $2800-6400$ \\
\hline $25-34$ & $150-2982$ & $30-39$ & $1200-5200$ \\
\hline $35-49$ & $150-2582$ & $40-49$ & $950-5300$ \\
\hline $50-59$ & $260-2000$ & $50-59$ & $700-3100$ \\
\hline $60-69$ & $130-1300$ & $60-69$ & $420-2900$ \\
\hline $70-79$ & $280-1750$ & $70-89$ & $280-1750$ \\
\hline
\end{tabular}

Table 1. References ranges for DHEAS levels (ng/mL).

$(5.0 \mu \mathrm{g} / \mathrm{dL})^{2}$, but also the $50 \mathrm{nmol} / \mathrm{L}(1.8 \mu \mathrm{g} / \mathrm{dL})$ and $83 \mathrm{nmol} / \mathrm{L}(3.0 \mu \mathrm{g} / \mathrm{dL})$ cut-off values. For the evaluation of the diagnosis accuracy of the DST for the identification of comorbidities potentially related to ACS, the $>50 \mathrm{nmol} / \mathrm{L}$ threshold was employed, based on the results of the ROC curves and on previous studies that found that this cut-off was the most sensitive for this purpose ${ }^{11-15}$. UFC levels above the upper limit of the reference range in our laboratory were considered elevated. Besides, patients with UFC levels within the reference range were classified into two groups-normal-low or normal-high UFC levels-using $1930 \mathrm{nmol} / 24 \mathrm{~h}$ $(70 \mu \mathrm{g} / 24 \mathrm{~h})$ as threshold, because this was the value that associated the highest specificity for the diagnosis of ACS according to the results of the ROC curve. Patients with UFC levels two-fold above the reference range were diagnosed with overt Cushing's syndrome and excluded from the study (Fig. 1). ACTH levels below 2 pmol/L $(10 \mathrm{pg} / \mathrm{mL})$ were considered low. LNSC levels above the upper limit of the reference range in our laboratory were considered elevated. DHEA-S levels were considered to be elevated or decreased according to age- and sex-specific reference ranges in our laboratory.

Laboratory assays. As we have previously reported ${ }^{16}$, urine and serum cortisol were measured by immunochemiluminescence assays in an Architect i2000 systems Abbott Diagnostics platform, with an intra-assay coefficient of variation $(\mathrm{CV})<10 \%$; the normal range was $102-535 \mathrm{nmol} / \mathrm{L}(3.7-19.4 \mu \mathrm{g} / \mathrm{dL})$ for serum cortisol and $<3862 \mathrm{nmol} / 24 \mathrm{~h}(140 \mu \mathrm{g} / 24 \mathrm{~h})$ for 24 -h urine cortisol. LNSC was measured by electroimmunochemiluminescence in a Cobas 6000 Roche autoanalyser, with an intra-assay $\mathrm{CV}<10 \%$ and a reference range lower than $157 \mathrm{nmol} / \mathrm{L}(<5.7 \mu \mathrm{g} / \mathrm{dL})$. The determination of ACTH was performed by immunochemiluminescence assays (we used Immulite 2000 Siemens before 2019 and Liaison XL Diasorin thereafter), with an intra-assay CVs $<10 \%$. Normal values for ACTH were between $2.0-10.1 \mathrm{pmol} / \mathrm{L}(9-46 \mathrm{pg} / \mathrm{mL})$ for the Immulite assay and $1.0-10.7 \mathrm{pmol} / \mathrm{L}(5-49 \mathrm{pg} / \mathrm{mL})$ for the Liaison XL assay. DHEA-S was measured by immunochemiluminescence assay in Immulite 2000 Siemens system; with intra-assay CV $<15 \%$. Reference ranges for DHEA-S were age- and sex-specific (Table 1).

Imaging studies. At diagnosis, abdominal computed tomography or magnetic resonance imaging were obtained in all AIs patients. Tumour size (largest diameter), uni- or bilaterality, presence of necrosis, calcification and atypical characteristics, lipid content and radiodensity measured in Hounsfield units (HU) were registered. In bilateral AIs, the recorded tumour size was that of the largest AI. The adrenal tumour was classified as having rich lipid content when attenuation was low $(<10 \mathrm{HU})$ in a CT performed without contrast administration or when the washout in a CT with contrast was rapid ( $>60 \%$ absolute washout or $>40 \%$ relative washout $)^{4}$. Computed tomography was repeated in 99 patients and magnetic resonance imaging was repeated in 80 patients during follow-up.

Statistical analysis. We checked continuous variables for normality using the Shapiro-Wilk test, and for homogeneity of the variances using Levene's test. Categorical variables were expressed as counts and percentages, whereas continuous variables were expressed as mean \pm standard deviation or median and interquartile range (IQR) as appropriate. Odds ratios (with 95\% confidence intervals) and mean differences were calculated as association measures using logistic regression models or lineal regression $\beta$ coefficients. For variables following the normal distribution, we used Student's $t$ test to compare differences between two groups. The chi-square test was used for the comparison of categorical variables between independent groups. Cox regression analysis was used to estimate hazard ratios during follow-up. Reliability was evaluated with the kappa index and the specific positive and negative agreement indexes. Nonparametric receiver-operator curve (ROC) analysis was used to determine the diagnostic accuracy for the diagnosis of ACS, and of comorbidities potentially related to ACS, of the different hormonal tests, either individually or in combination. In all cases, a two-tailed $P$ value $<0.05$ was considered as statistically significant. All statistical analyses were performed using STATA 15 (StataCorp. 2017. Stata Statistical Software: Release 15. College Station, TX: StataCorp LLC).

Ethical approval. All procedures performed in the participants of the study were in accordance with the ethical standards of the institutional research committee and with the 1964 Helsinki declaration and its later amendments or comparable ethical standards. The study was approved by the Ethics Committee of Hospital Universitario Ramón y Cajal on February 14, 2019. 


\begin{tabular}{|c|c|}
\hline Parameter & Value \\
\hline \multicolumn{2}{|l|}{ Clinical data } \\
\hline Age, years & $64.5 \pm 10.0$ \\
\hline Female sex & $57.4 \%(\mathrm{n}=113)$ \\
\hline Comorbidities potentially related to ACS & $85.9 \%(\mathrm{n}=152)$ \\
\hline Diabetes & $22.3 \%(\mathrm{n}=44)$ \\
\hline Hypertension & $57.9 \%(\mathrm{n}=114)$ \\
\hline Dyslipidaemia & $49.0 \%(n=96)$ \\
\hline Obesity & $31.0 \%(\mathrm{n}=61)$ \\
\hline Cerebrovascular disease & $1.0 \%(\mathrm{n}=2)$ \\
\hline Cardiovascular disease & $10.7 \%(\mathrm{n}=21)$ \\
\hline Body mass index $\left(\mathrm{kg} / \mathrm{m}^{2}\right)(\mathrm{n}=133)$ & $30.3 \pm 6.3$ \\
\hline Systolic blood pressure $(\mathrm{mmHg})(\mathrm{n}=159)$ & $137.7 \pm 16.9$ \\
\hline Diastolic blood pressure $(\mathrm{mmHg})(\mathrm{n}=159)$ & $79.7 \pm 9.6$ \\
\hline \multicolumn{2}{|l|}{ Analytical data } \\
\hline Fasting plasma glucose, $\mathrm{nmol} / \mathrm{L}(\mathrm{mg} / \mathrm{dL})(\mathrm{n}=197)$ & $5.87 \pm 1.6(105.7 \pm 28.9)$ \\
\hline $\operatorname{HbA1c}(\%)(\mathrm{n}=55)$ & $6.2 \pm 0.9$ \\
\hline LDL-c, nmol/L (mg/dL) (n=143) & $30.03 \pm 8.3(115.5 \pm 31.8)$ \\
\hline HDL-c, nmol/L (mg/dL) $(\mathrm{n}=143)$ & $13.96 \pm 4.6(53.7 \pm 17.7)$ \\
\hline Triglycerides, nmol/L (mg/dL) $(\mathrm{n}=193)$ & $1.17 \pm 0.6(110.2 \pm 51.1)$ \\
\hline DST, nmol/L $(\mu \mathrm{g} / \mathrm{dL})(\mathrm{n}=197)$ & $66.2 \pm 74.5(2.4 \pm 2.7)$ \\
\hline Urinary free cortisol, $\mathrm{nmol} / 24 \mathrm{~h}(\mu \mathrm{g} / 24 \mathrm{~h})(\mathrm{n}=197)$ & $1092.41 \pm 791.1(39.6 \pm 28.7)$ \\
\hline ACTH, pmol/L $(\mathrm{pg} / \mathrm{mL})(\mathrm{n}=197)$ & $3.59 \pm 2.6(16.3 \pm 11.6)$ \\
\hline DHEAS $(\mathrm{ng} / \mathrm{mL})(\mathrm{n}=197)$ & $596.2[\mathrm{IQR}=150-2840]$ \\
\hline Late-night salivary cortisol, $\mathrm{nmol} / \mathrm{L}(\mu \mathrm{g} / \mathrm{dL})(\mathrm{n}=197)$ & $110.3 \pm 118.6(4.0 \pm 4.3)$ \\
\hline \multicolumn{2}{|l|}{ Radiological data } \\
\hline Tumor size $(\mathrm{mm})(\mathrm{n}=197)$ & $22.2 \pm 10.5$ \\
\hline Bilaterality $(n=197)$ & $30.0 \%(\mathrm{n}=59)$ \\
\hline Tumor rich in lipidic content $(\mathrm{n}=155)$ & $85.2 \%(\mathrm{n}=132)$ \\
\hline
\end{tabular}

Table 2. Baseline characteristics of the cohort $(\mathrm{n}=197)$. ACTH adrenocorticotropic hormone, ACS autonomous cortisol secretion, DST dexamethasone suppresion test, DHEAS dehydroepiandrosterone sulphate, $L D L-c$ low-density lipoprotein cholesterol, $H D L-c$ high-density lipoprotein cholesterol, $H b A 1 c$ hemoglobin A1c.

Informed consent. The Ethical committee of Hospital Universitario Ramón y Cajal approved the waiver for informed consent given the retrospective nature of the study.

\section{Results}

Cardiometabolic profile at diagnosis and during follow-up. Following inclusion and exclusion criteria, 197 patients - of a total of 709 patients with AIs consecutively evaluated between 2013 and 2020 at our centre-were included in the analysis. No statistically significant differences were detected between the patients with AIs included or excluded in the study with the exception of higher cortisol post-DST, lower ACTH levels and a larger tumour size in the former (Supplementary Material Table S1). Baseline characteristics of the cohort included in the present study are summarized in Table 2. At diagnosis, 19 patients (9.6\%) had ACS (as defined by a post-DST cortisol $>138 \mathrm{nmol} / \mathrm{L}$ ) and 169 patients $(85.9 \%)$ presented with one or more comorbidities potentially related to ACS. The prevalence of obesity was of $31 \%$, yet no statistically significant differences in the postDST cortisol levels were found between patients with and without obesity $(59 \pm 49 \mathrm{nmol} / \mathrm{L}$ vs $71 \pm 82 \mathrm{nmol} / \mathrm{L}$, respectively, $\mathrm{P}=0.316$ ). Four patients presenting with non-functioning AIs $>4 \mathrm{~cm}$ underwent adrenalectomy, and active surveillance was carried out in the remainder. After a median follow-up of 30.6 (IQR $=2.0-114.7$ ) months, 6 out of 120 patients with non-functioning AIs developed ACS and 23 patients developed one or more new comorbidities: 20 (23.0\%) developed dyslipidaemia; 6 (8.8\%) developed hypertension; 9 (11.5\%) became obese; 6 (4.5\%) were diagnosed with type 2 diabetes; and 5 (3.2\%) suffered a cardiovascular event. No cerebrovascular events were registered during follow-up.

Reliability and accuracy of LNSC, UFC, ACTH and DHEAS for the diagnosis of ACS. The degree of agreement (reliability) of LNSC, UFC, ACTH and DHEA-S for the diagnosis of ACS was low, independently of the DST threshold used for the definition of ACS, with kappa indexes below 0.3 for all tests. However, the specific negative agreement was high, around $80-90 \%$. Regarding their validity, the highest specificity was reached when ACS definition was based on the $138 \mathrm{nmol} / \mathrm{L}(5.0 \mu \mathrm{g} / \mathrm{dL})$ threshold. Nevertheless, all tests had poor sensitivity for the diagnosis of ACS independently of the DST threshold employed for the diagnosis of ACS (Table 3). 


\begin{tabular}{|c|c|c|c|c|c|c|c|}
\hline & Kappa index & Specific Po+ $(\%)$ & Specific Po- (\%) & Sensitivity (\%) & Specificity (\%) & PPV (\%) & NPV (\%) \\
\hline \multicolumn{8}{|c|}{ Considering the gold standard of ACS a DST $>138 \mathrm{nmol} / \mathrm{L}(5.0 \mu \mathrm{g} / \mathrm{dL})$} \\
\hline UFC $>1931 \mathrm{nmol} / 24 \mathrm{~h}$ & 0.157 & 24.4 & 91.2 & 26.3 & 90.4 & 22.7 & 92.0 \\
\hline $\mathrm{ACTH}<2 \mathrm{pmol} / \mathrm{L}$ & 0.039 & 18.4 & 76.9 & 42.1 & 66.3 & 11.8 & 91.5 \\
\hline $\mathrm{LNSC}>157 \mathrm{nmol} / \mathrm{L}$ & 0.283 & 36.7 & 91.0 & 47.4 & 88.2 & 30.0 & 94.0 \\
\hline $\begin{array}{l}\text { Low sex- and age- } \\
\text { adjusted DHEA-S }\end{array}$ & 0.082 & 20.9 & 83.8 & 36.8 & 77.0 & 14.6 & 91.9 \\
\hline \multicolumn{8}{|c|}{ Considering the gold standard of ACS a DST $>83.0 \mathrm{nmol} / \mathrm{L}(3.0 \mu \mathrm{g} / \mathrm{dL})$} \\
\hline UFC $>1931 \mathrm{nmol} / 24 \mathrm{~h}$ & 0.239 & 34.9 & 87.6 & 26.8 & 92.9 & 50.0 & 82.9 \\
\hline ACTH $<2 \mathrm{pmol} / \mathrm{L}$ & 0.145 & 36.7 & 75.8 & 48.8 & 69.2 & 29.4 & 83.7 \\
\hline LNSC $>157 \mathrm{nmol} / \mathrm{L}$ & 0.231 & 36.6 & 86.1 & 31.7 & 89.1 & 43.3 & 83.2 \\
\hline $\begin{array}{l}\text { Low sex- and age- } \\
\text { adjusted DHEA-S }\end{array}$ & 0.116 & 31.5 & 80.0 & 34.1 & 78.2 & 29.2 & 81.9 \\
\hline \multicolumn{8}{|c|}{ Considering the gold standard of ACS a DST $>50.0 \mathrm{nmol} / \mathrm{L}(1.8 \mu \mathrm{g} / \mathrm{dL})$} \\
\hline UFC $>1931 \mathrm{nmol} / 24 \mathrm{~h}$ & 0.086 & 24.5 & 75.0 & 15.8 & 91.7 & 54.5 & 63.4 \\
\hline $\mathrm{ACTH}<2 \mathrm{pmol} / \mathrm{L}$ & 0.235 & 51.4 & 72.0 & 48.7 & 74.4 & 54.4 & 69.8 \\
\hline LNSC $>157 \mathrm{nmol} / \mathrm{L}$ & 0.179 & 35.8 & 76.4 & 25.0 & 90.9 & 63.3 & 65.9 \\
\hline $\begin{array}{l}\text { Low sex- and age- } \\
\text { adjusted DHEA-S }\end{array}$ & 0.103 & 37.1 & 71.1 & 30.3 & 79.3 & 47.9 & 64.4 \\
\hline
\end{tabular}

Table 3. Reliability and validity of LNSC, UFC, ACTH and DHEAS for the diagnosis of ACS (considering three different thresholds in the DST for the ACS definition). ACTH adrenocorticotropic hormone, DST dexamethasone suppression test, DHEAS dehydroepiandrosterone sulphate, LNSN late-night salivary cortisol, $P P V$ positive predictive value, $N P V$ negative predictive value, Specific $P o+$ specific positive agreement index, Specific Po-specific negative agreement index, UFC urinary-free cortisol.

ROC curves confirmed these findings, supporting that these tests should not be used in isolation for the diagnosis of ACS. The greatest diagnostic accuracy, although modest, was that of LNSC (Figs. 2, 3). Moreover, when the four tests were combined, the diagnostic accuracy for the diagnosis of ACS increased, reaching an AUC of $0.73[0.65-0.80]$.

Association of the individual ACS diagnostic tests' results with comorbidities potentially related to ACS. Seventy-six (38.6\%) patients showed a DST serum cortisol level $>50 \mathrm{nmol} / \mathrm{L}(1.8 \mu \mathrm{g} / \mathrm{dL})$ at diagnosis. These patients had a risk of comorbidities potentially related to ACS two-fold higher than those with DST $\leq 50 \mathrm{nmol} / \mathrm{L}$. The prevalence of dyslipidaemia and hypertension in patients with DST $>50 \mathrm{nmol} / \mathrm{L}$ was 1.8 and 2.5 times higher than in patients with DST $\leq 50 \mathrm{nmol} / \mathrm{L}$, respectively (Table 4). However, the diagnostic performance of the DST to predict the presence of one or more comorbidities potentially related to ACS either individually or collectively, was poor, because all areas under the ROC curve analyses were below 0.67) (Fig. 4).

UFC was above the $>3862 \mathrm{nmol} / 24 \mathrm{~h}$ in $2(1.0 \%)$ patients whereas another $22(11.2 \%)$ subjects showed normal-high (1931-3862 nmol/24 h) UFC concentrations. The prevalence of hypertension was three times higher in patients with normal-high UFC than in patients with normal-low UFC $(<1931 \mathrm{nmol} / 24 \mathrm{~h})$ (Table 4$)$. LNSC was above the reference range in $30(15.2 \%)$ patients, who had higher prevalences of hypertension and lower HDL-c levels when compared with patients showing LNSC levels within the reference range (Table 4). Basal ACTH levels were $<2 \mathrm{pmol} / \mathrm{L}$ in $68(34.5 \%)$ patients and DHEAS levels were below the age and sex-adjusted reference ranges in $48(24.4 \%)$ patients. No differences were found in the prevalence of ACS-related comorbidities according to ACTH or DHEAS levels. The AUCs for the diagnosis of ACS-related comorbidities were poor for UFC, LNSC, ACTH and DHEAS levels; and do not even reaching that of the DST ROC curve (Fig. 4). Even, when the five tests (including the DST) were used in combination for the prediction of comorbidities potentially related to ACS, the AUC was modest with an AUC of 0.70 [0.58-0.82].

When we evaluated the combined use of the tests for the diagnosis of comorbidities potentially related to ACS, the best association was that of the combination of a DST $>50 \mathrm{nmol} / \mathrm{L}$ and a LNSC $>149 \mathrm{nmol} / \mathrm{L}$, which was present in 19 patients in our cohort. These patients had increased risks of hypertension (OR 7.1, 95\% CI 1.6-31.6) and cardiovascular events (OR 3.6, 95\% CI 1.2-11.3) (Table 5).

\section{Discussion}

Our study confirms that, when used as single tests, plasma ACTH, LNSC, UFC and DHEA-S had poor sensitivity for the diagnosis of ACS. The combination of the four tests, however, improved diagnostic accuracy for ACS reaching an AUC in the ROC curve of 0.73 . On the other hand, the diagnosis accuracy of DST for the prediction of comorbidities potentially related to ACS is low, albeit other tests routinely used for the study of AIs showed even worse performances. The association of a positive DST test with hypertension and cardiovascular events seems to increase when combined with increased LNSC levels, with the addition of ACTH, DHEA-S or UFC not improving the strength of such an association.

Several studies found that patients with AIs and elevated post-DST cortisol concentrations had worse cardiometabolic profiles and increased mortality compared with patients reaching adequate cortisol suppression 


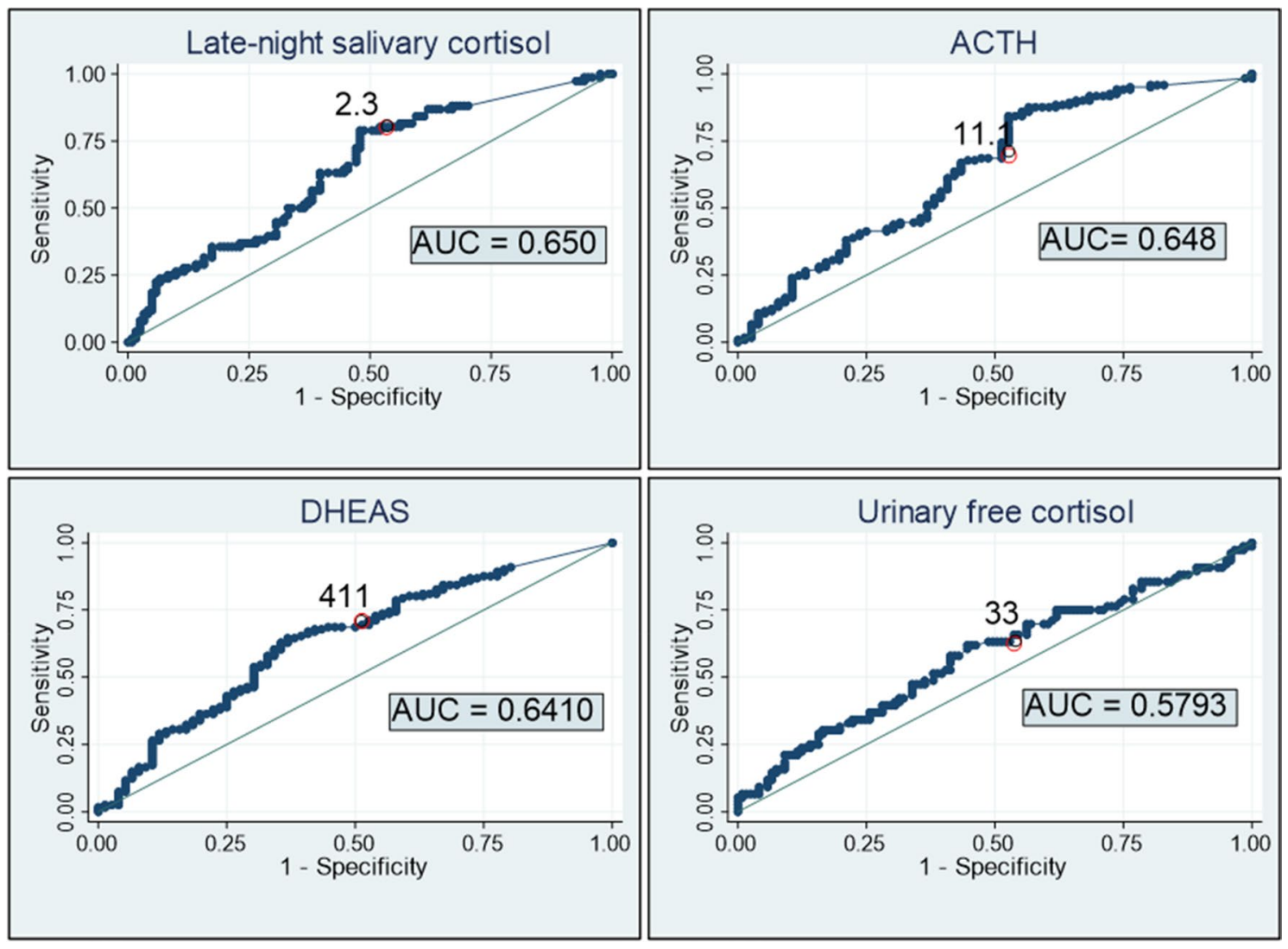

Figure 2. Diagnosis accuracy of LNSC, ACTH, DHEAS and UFC for the diagnosis of ACS (considering the $1.8 \mu \mathrm{g} / \mathrm{dL}$ threshold for the diagnosis of Autonomous cortisol secretion). Optimal cutoff point based on ROC curve $2.26 \mu \mathrm{g} / \mathrm{dL}$ (Sensitivity: $\mathrm{Se}=78.9 \%$ (95\% CI 68.5 to 86.6 ) and Specificity: $\mathrm{Sp}=52.1 \%$ (95\% CI 43.2 to 60.8). ACTH AUC $0.648,95 \%$ CI $0.577-0.715$. Optimal cutoff point based on ROC curve: $11.08 \mathrm{pg} / \mathrm{mL}(\mathrm{Se}=66.9 \%$ (95\% CI 58.2 to 74.7$)$ and $\mathrm{Sp}=56.6 \%$ (95\% CI 45.4 to 67.1). DHEA-S AUC 0.640, 95\% CI 0.570-0.708. Optimal cutoff point based on ROC curve: $411 \mu \mathrm{g} / \mathrm{dL}$ ( $\mathrm{Se}=64.5 \%$ (95\% CI 55.6 to 72.4 ) and $\mathrm{Sp}=63.2 \%$ (95\% CI 51.9 to 73.1). 24 h-urinary free cortisol (UFC) AUC 0.579, 95\%CI 0.507-0.649. Optimal cutoff point based on ROC curve $32.6 \mu \mathrm{g} / 24 \mathrm{~h}$ ( $\mathrm{Se}=61.8 \%$ (95\% CI 50.6 to 71.9 and $\mathrm{Sp}=55.4 \%$ (95\% CI 46.5 to 63.9 ).

after this test ${ }^{11-13,17}$. It is currently debated which DST threshold should be used for the diagnosis of ACS. Several studies suggested that $50 \mathrm{nmol} / \mathrm{L}$ is the most sensitive threshold to identify patients with AIs and increased cardiometabolic risk ${ }^{11-15}$. In this line, Morelli et al. ${ }^{14}$ demonstrated that in patients with AI, post-DST cortisol levels increased according to the number of chronic complications. In another study ${ }^{15}$, using artificial neural networks, she found that the optimal cut-off of post-DST cortisol levels for detecting patients with increased cardiovascular events was $50 \mathrm{nmol} / \mathrm{L}$ (accuracy 67.3\%, AUC, 0.673). Furthermore, in another study ${ }^{18}$ an increased risk of cardiovascular events was observed with post-DST cortisol values above $41 \mathrm{nmol} / \mathrm{L}(1.5 \mu \mathrm{g} / \mathrm{dL})$. Our study found that, although there were some associations between DST results and cardiometabolic comorbidities, the DST had a poor diagnostic performance for the presence of these comorbidities. This finding is in agreement with earlier studies ${ }^{14,15,18}$, supporting that post-DST cortisol is neither accurate enough to predict the occurrence of post-surgical hypocortisolism nor the improvement of surgical complications in patients with AIs.

The poor performance of the DST and other tests of adrenal function on the prediction of comorbidities potentially related to ACS might be explained by the multifactorial origin of these prevalent cardiometabolic disorders. Hence, ACS as a single factor, is unlikely to fully predict them especially when some factors known to increase the cardiometabolic risk such as older age ${ }^{19}$ and subclinical co-secretion of other hormones like aldosterone ${ }^{20}$ are also associated with the presence of AIs. Other factors such as obesity, which can promote hyperinsulinism and thus the development of AIs, could be indirectly associated with cortisol production as well ${ }^{21}$. However, until better and or reliable markers of ACS become available, the DST using the serum cortisol level $>1.8 \mu \mathrm{g} / \mathrm{dL}$ threshold seems the most sensitive single test to identify ACS patients at risk of cardiometabolic comorbidities. Moreover, in the presence of an elevated post-DST cortisol concentration, an elevated LNSC identifies patients at even higher cardiometabolic risk.

The performance of UFC, DHEA-S, ACTH and LNSC levels for the diagnosis of ACS was poor and, for the identification of comorbidities potentially related to ACS, were even poorer than that of DST in our study. This finding supports the recommendation of most professional societies to use the DST for the evaluation of ACS in $\mathrm{AIs}^{4,7,8}$. At present, UFC is not recommended for the diagnosis of ACS, given that less than $20 \%$ of patients with ACS present elevated UFC levels ${ }^{5,22}$. The role of DHEA-S in the diagnosis of ACS is currently controversial ${ }^{23-27}$. 

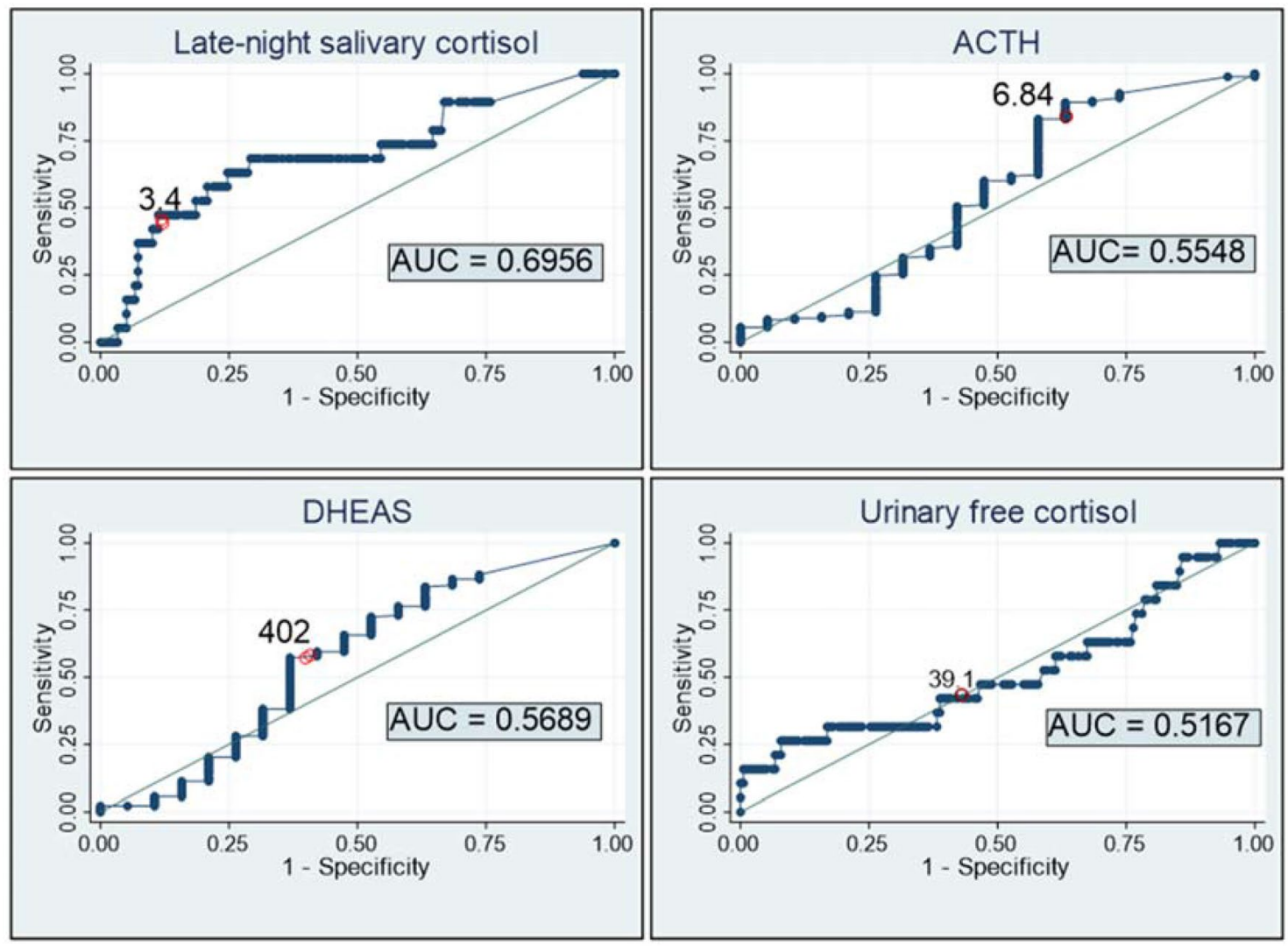

Figure 3. Diagnosis accuracy of LNSC, ACTH, DHEAS and UFC for the diagnosis of ACS (considering the $5 \mu \mathrm{g} / \mathrm{dL}$ threshold for the diagnosis of Autonomous cortisol secretion). Late-night salivary cortisol AUC $=0.696$ (95\% CI 0.626 to 0.759 ). Optimal cut-off point based on ROC curve: $3.4 \mu \mathrm{g} / \mathrm{dL}$ ( $\mathrm{Se}=68.4 \%$ (95\% CI 46.0 to 84.6) and $\mathrm{Sp}=70.8 \%$ (95\% CI 63.7 to 77.0). ACTH AUC $=0.555$ (95\% CI 0.483 to 0.625). Optimal cut-off point based on ROC curve: $6.84 \mathrm{pg} / \mathrm{mL}$ ( $\mathrm{Se}=83.1 \%$ (95\% CI 77.0 to 87.9) and $\mathrm{Sp}=42.1 \%$ (95\% CI 23.1 to 63.7). DHEAS AUC $=0.569$ (95\% CI 0.497 to 0.639$)$. Optimal cut-off point based on ROC curve: $402 \mu \mathrm{g} / \mathrm{dL}$ (Se $=57.3 \%(95 \%$ CI 50.0 to 64.3 ) and $\mathrm{Sp}=63.2 \%$ (95\% CI 41.0 to 80.9). UFC AUC 0.517 (95\% CI 0.445 to 0.588 ). Optimal cut-off point based on ROC curve: $39.1 \mu \mathrm{g} / 24 \mathrm{~h}(\mathrm{Se}=42.1 \%(95 \% \mathrm{CI} 23.1$ to 63.7$)$ and $\mathrm{Sp}=61.2 \%$ (95\% CI 53.9 to 68.1).

In our study, DHEA-S as a single test or in combination with DST did not achieve better diagnostic performances for comorbidities potentially related to ACS than using the DST alone. Previous studies found basal ACTH levels $>2 \mathrm{pmol} / \mathrm{L}$ in up to $50 \%$ of patients with ACS and $<2 \mathrm{pmol} / \mathrm{L}$ in as many as $20 \%$ of patients with normal cortisol metabolism, also suggesting a poor diagnostic performance for ACS ${ }^{28}$. We found basal ACTH levels to have a weak association with the results of the DST, but no association with cardiometabolic comorbidities. LNSC - an easy, stress-free, and cost-effective alternative to late night serum cortisol-also showed limited utility for the diagnosis of ACS as suggested by previous studies ${ }^{29}$. Of the tests of adrenal function studied here, LNSC levels showed the greater reliability for the diagnosis of ACS as defined by the DST test, and patients with elevated LNSC and post-DST cortisol levels were those with the worst cardiometabolic profiles. Moreover, we found that the combination of basal plasma ACTH, UFC, LNSC and DHEA-S significantly increased the diagnostic accuracy for the diagnosis of ACS compared with their use as single tests, reaching an AUC of 0.73 in the ROC curve. This is in line with the recommendation of most guidelines and experts in this field of using the combination of several hormonal parameters to evaluate the presence of $\mathrm{ACS}^{2,4-10}$.

Our present study, however, is not free of limitations, starting by its retrospective design. Because we only included patients in whom all the diagnostic tests had been obtained, and such a decision was made on a clinical basis by their physicians, possibility exists of a selection bias towards the inclusion of a subset of more complicated patients as higher tumour size, higher DST and lower ACTH levels were found in the inclusion population compared to the excluded patients. However, we included all consecutive patients fulfilling the inclusion criteria during the study period within a single institution, thus allowing for comparable laboratory results. We did not evaluate osteoporosis, which is a recognized comorbidity related to ACS, due to inconsistent evaluation in the medical records. Therefore, the association of the results of the different evaluated tests with osteoporosis could not be evaluated. The metabolism of dexamethasone varies widely among patients ${ }^{30}$. Although we excluded patients with known factors associated with false positive results in the DST such as treatment with oral hormone 


\begin{tabular}{|c|c|c|c|c|c|}
\hline & $\begin{array}{l}\operatorname{DST}(n m o l / L)>50(n=76) \\
\text { vs } \leq 50(n=121)\end{array}$ & $\begin{array}{l}\text { UFC }(\mathrm{nmol} / 24 \mathrm{~h}) \geq 1930 \\
(\mathrm{n}=22) \text { vs }<1930(\mathrm{n}=175)\end{array}$ & $\begin{array}{l}\text { ACTH }(\mathrm{pmol} / \mathrm{L})<2(\mathrm{n}=68) \\
\text { vs } \geq 2(\mathrm{n}=129)\end{array}$ & $\begin{array}{l}\text { DHEAS }(\mu \mathrm{g} / \mathrm{dL}) \text { low } \\
(\mathrm{n}=48) \text { vs normal }(n=149)\end{array}$ & $\begin{array}{l}\operatorname{LNSC}(n m o l / L)>157 \\
(n=30) \text { vs } \leq 157(n=167)\end{array}$ \\
\hline Age, years & $\begin{array}{l}65.7 \pm 10.0 \text { vs } 63.7 \pm 10.1 \\
P=0.173\end{array}$ & $\begin{array}{l}64.6 \pm 10.0 \text { vs } 64.5 \pm 10.1 \\
P=0.943\end{array}$ & $\begin{array}{l}63.3 \pm 9.2 \text { vs } 65.1 \pm 10.5 \\
P=0.252\end{array}$ & $\begin{array}{l}64.3 \pm 10.1 \text { vs } 64.5 \pm 10.1 \\
P=0.885\end{array}$ & $\begin{array}{l}66.9 \pm 10.8 \text { vs } 64.1 \pm 9.9 \\
\mathrm{P}=0.154\end{array}$ \\
\hline Male sex & OR $0.8[0.5-1.4], \mathrm{P}=0.476$ & OR 1.4 [0.6-3.4], $\mathrm{P}=0.461$ & OR $0.6[0.3-1.1], \mathrm{P}=0.068$ & OR $2.3[1.2-4.5], \mathrm{P}=0.012$ & OR $1.0[0.5-2.3], \mathrm{P}=0.934$ \\
\hline $\begin{array}{l}\text { Comorbidities potentially } \\
\text { related to ACS (composite) }\end{array}$ & OR 2.6[1.0-6.8], $\mathrm{P}=0.045$ & OR $1.7[0.4-8.0], \mathrm{P}=0.446$ & OR $1.7[0.7-4.6], \mathrm{P}=0.248$ & $=1.0[0.4-2.7], \mathrm{P}=0.971$ & OR $2.5[0.6-11.2], \mathrm{P}=0.188$ \\
\hline Hypertension & OR $2.5[1.4-4.6], \mathrm{P}=0.003$ & OR $2.7[1.0-7.7], \mathrm{P}=0.043$ & OR $1.0[0.5-1.8], \mathrm{P}=0.915$ & OR $0.8[0.4-1.6] \mathrm{P}=0.551$ & OR $2.7[1.1-6.7], \mathrm{P}=0.020$ \\
\hline Dyslipidaemia & OR $1.8[1.0-3.2], \mathrm{P}=0.054$ & OR $1.0[0.4-2.5], \mathrm{P}=0.940$ & OR $1.0[0.6-1.9], \mathrm{P}=0.877$ & OR $1.0[0.5-2.0], \mathrm{P}=0.903$ & OR $1.2[0.6-2.6], \mathrm{P}=0.626$ \\
\hline Obesity & OR 1.0 [0.6-1.9], $\mathrm{P}=0.883$ & OR $2.0[0.8-5.0], \mathrm{P}=0.130$ & OR $1.0[0.5-1.9], \mathrm{P}=0.986$ & OR $1.0[0.5-2.1], \mathrm{P}=0.961$ & OR $0.6[0.3-1.6], \mathrm{P}=0.316$ \\
\hline Diabetes & OR $1.6[0.8-3.2], \mathrm{P}=0.161$ & OR $1.7[0.7-4.6], \mathrm{P}=0.275$ & OR 1.1[0.6-2.2], $\mathrm{P}=0.771$ & OR 1.0[0.5-2.3], $\mathrm{P}=0.912$ & OR 1.1[0.4-2.7], $\mathrm{P}=0.887$ \\
\hline Cardiovascular disease & OR 2.3[0.9-5.8], $\mathrm{P}=0.069$ & OR 1.4[0.4-5.1], $\mathrm{P}=0.642$ & OR $0.9[0.4-2.5], \mathrm{P}=0.904$ & OR 1.6[0.6-4.4], $\mathrm{P}=0.326$ & OR $1.9[0.6-5.6], P=0.273$ \\
\hline Cerebrovascular disease & OR 1.6[0.1-26.0], $\mathrm{P}=0.742$ & $\mathrm{NC}$ & OR $1.9[0.1-31.0], \mathrm{P}=0.652$ & OR $3.1[0.2-51.3], \mathrm{P}=0.432$ & $\mathrm{NC}$ \\
\hline $\begin{array}{l}\text { Body mass index }\left(\mathrm{kg} / \mathrm{m}^{2}\right) \\
(\mathrm{n}=133)\end{array}$ & $\begin{array}{l}30.4 \pm 6.6 \text { vs } 30.2 \pm 6.2 \\
P=0.866\end{array}$ & $\begin{array}{l}31.6 \pm 5.8 \text { vs } 30.2 \pm 6.4 \\
P=0.444\end{array}$ & $\begin{array}{l}30.5 \pm 7.1 \text { vs } 30.2 \pm 6.0 \\
P=0.824\end{array}$ & $\begin{array}{l}30.2 \pm 5.4 \text { vs } 30.4 \pm 6.7 \\
\mathrm{P}=0.932\end{array}$ & $\begin{array}{l}31.4 \pm 7.1 \text { vs } 30.2 \pm 6.2 \\
P=0.447\end{array}$ \\
\hline $\begin{array}{l}\text { Systolic blood pressure } \\
(\mathrm{n}=159)\end{array}$ & $\begin{array}{l}136.9 \pm 16.3 \text { vs } 138.2 \pm 17.3 \\
P=0.642\end{array}$ & $\begin{array}{l}138.8 \pm 16.3 \text { vs } 137.5 \pm 17.0 \\
P=0.779\end{array}$ & $\begin{array}{l}135.9 \pm 16.1 \text { vs } 136.8 \pm 17.2 \\
P=0.352\end{array}$ & $\begin{array}{l}137.8 \pm 18.2 \text { vs } 137.6 \pm 16.5 \\
P=0.971\end{array}$ & $\begin{array}{l}137.2 \pm 19.1 \text { vs } 137.8 \pm 16.5 \\
P=0.889\end{array}$ \\
\hline $\begin{array}{l}\text { Diastolic blood pressure } \\
(\mathrm{n}=159)\end{array}$ & $\begin{array}{l}78.4 \pm 9.6 \text { vs } 80.7 \pm 9.6 \\
P=0.136\end{array}$ & $\begin{array}{l}76.9 \pm 9.4 \text { vs } 80.1 \pm 9.6 \\
P=0.198\end{array}$ & $\begin{array}{l}77.9 \pm 7.6 \text { vs } 80.6 \pm 10.4 \\
P=0.095\end{array}$ & $\begin{array}{l}76.4 \pm 9.9 \text { vs } 80.9 \pm 9.3 \\
P=0.009\end{array}$ & $\begin{array}{l}78.6 \pm 7.3 \text { vs } 79.9 \pm 10.0 \\
P=0.541\end{array}$ \\
\hline $\begin{array}{l}\text { Fasting plasma glucose } \\
(\mathrm{nmol} / \mathrm{L})(\mathrm{n}=197)\end{array}$ & $6.7 \pm 2.3$ vs $6.1 \pm 1.2 \mathrm{P}=0.015$ & $\begin{array}{l}6.7 \pm 2.3 \text { vs } 6.3 \pm 1.7 \\
P=0.376\end{array}$ & $\begin{array}{l}6.3 \pm 1.7 \text { vs } 6.4 \pm 1.8 \\
P=0.837\end{array}$ & $\begin{array}{l}6.8 \pm 2.5 \text { vs } 6.2 \pm 1.4 \\
P=0.053\end{array}$ & $\begin{array}{l}6.1 \pm 1.2 \text { vs } 6.4 \pm 1.8 \\
P=0.504\end{array}$ \\
\hline HbAlc $(\%)(n=55)$ & $6.4 \pm 1.0$ vs $6.1 \pm 0.8 \mathrm{P}=0.225$ & $\begin{array}{l}6.3 \pm 0.8 \text { vs } 6.2 \pm 0.9 \\
P=0.799\end{array}$ & $\begin{array}{l}6.0 \pm 0.8 \text { vs } 6.3 \pm 1.0 \\
P=0.346\end{array}$ & $\begin{array}{l}6.2 \pm 1.0 \text { vs } 6.2 \pm 0.9 \\
P=0.826\end{array}$ & $\begin{array}{l}6.2 \pm 0.7 \text { vs } 6.2 \pm 1.0 \\
P=0.820\end{array}$ \\
\hline LDL-c $(\mathrm{mmol} / \mathrm{L})(\mathrm{n}=143)$ & $\begin{array}{l}29.9 \pm 7.8 \text { vs } 30.1 \pm 8.6 \\
\mathrm{P}=0.860\end{array}$ & $\begin{array}{l}30.3 \pm 9.6 \text { vs } 30.0 \pm 8.1 \\
P=0.859\end{array}$ & $\begin{array}{l}31.4 \pm 7.0 \text { vs } 29.4 \pm 8.8 \\
\mathrm{P}=0.164\end{array}$ & $\begin{array}{l}28.4 \pm 6.7 \text { vs } 30.6 \pm 8.7 \\
\mathrm{P}=0.148\end{array}$ & $\begin{array}{l}30.5 \pm 9.5 \text { vs } 29.9 \pm 8.1 \\
\mathrm{P}=0.755\end{array}$ \\
\hline HDL-c $(\mathrm{mmol} / \mathrm{L})(\mathrm{n}=143)$ & $\begin{array}{l}13.1 \pm 4.2 \text { vs } 14.5 \pm 4.8 \\
\mathrm{P}=0.079\end{array}$ & $\begin{array}{l}13.6 \pm 5.5 \text { vs } 14.0 \pm 4.5 \\
\mathrm{P}=0.747\end{array}$ & $\begin{array}{l}13.8 \pm 4.0 \text { vs } 14.0 \pm 4.9 \\
\mathrm{P}=0.835\end{array}$ & $\begin{array}{l}12.6 \pm 4.6 \text { vs } 14.4 \pm 4.5 \\
\mathrm{P}=0.035\end{array}$ & $\begin{array}{l}11.7 \pm 4.2 \text { vs } 14.4 \pm 4.6 \\
\mathrm{P}=0.012\end{array}$ \\
\hline $\begin{array}{l}\text { Triglycerides }(\mathrm{mmol} / \mathrm{L}) \\
(\mathrm{n}=193)\end{array}$ & $\begin{array}{l}1.2 \pm 0.6 \text { vs } 1.1 \pm 0.5 \\
\mathrm{P}=0.256\end{array}$ & $\begin{array}{l}1.0 \pm 0.3 \text { vs } 1.1 \pm 0.5 \\
\mathrm{P}=0.278\end{array}$ & $\begin{array}{l}1.0 \pm 0.1 \text { vs } 1.2 \pm 0.5 \\
\mathrm{P}=0.033\end{array}$ & $\begin{array}{l}1.1 \pm 0.5 \text { vs } 1.1 \pm 0.5 \\
P=0.693\end{array}$ & $\begin{array}{l}1.1 \pm 0.4 \text { vs } 1.1 \pm 0.5 \\
\mathrm{P}=0.974\end{array}$ \\
\hline $\operatorname{DST}(\mathrm{nmol} / \mathrm{L})(\mathrm{n}=197)$ & $\begin{array}{l}121.0 \pm 95.2 \text { vs } 33.0 \pm 9.13 \\
\mathrm{P}<0.0001\end{array}$ & $\begin{array}{l}107.4 \pm 117.8 \text { vs } 61.9 \pm 64.3 \\
P=0.006\end{array}$ & $\begin{array}{l}75.2 \pm 59.0 \text { vs } 62.7 \pm 79.6 \\
P=0.253\end{array}$ & $\begin{array}{l}86.0 \pm 105.8 \text { vs } 60.9 \pm 58.1 \\
\mathrm{P}=0.039\end{array}$ & $\begin{array}{l}117.5 \pm 21.2 \text { vs } 57.9 \pm 58.6 \\
\mathrm{P}<0.0001\end{array}$ \\
\hline ACTH $(\mathrm{pmol} / \mathrm{L})(\mathrm{n}=197)$ & $\begin{array}{l}3.0 \pm 2.42 \text { vs } 4.0 \pm 2.42 \\
\mathrm{P}=0.011\end{array}$ & $\begin{array}{l}4.6 \pm 3.1 \text { vs } 3.5 \pm 2.5 \\
P=0.056\end{array}$ & $\begin{array}{l}1.5 \pm 0.4 \text { vs } 4.7 \pm 2.5 \\
P<0.0001\end{array}$ & $\begin{array}{l}3.1 \pm 1.8 \text { vs } 3.8 \pm 2.8 \\
\mathrm{P}=0.110\end{array}$ & $\begin{array}{l}3.2 \pm 2.1 \text { vs } 3.6 \pm 2.6 \\
P=0.403\end{array}$ \\
\hline UFC $(\mathrm{nmol} / \mathrm{L})(\mathrm{n}=197)$ & $\begin{array}{l}1256.6 \pm 974.0 \text { vs } \\
988.7 \pm 635.1, P=0.020\end{array}$ & $\begin{array}{l}2811.6 \pm 883.5 \text { vs } \\
875.9 \pm 883.5, \mathrm{P}<0.0001\end{array}$ & $\begin{array}{l}983.9 \pm 647.3 \text { vs } \\
1149.1 \pm 855.2, P=0.165\end{array}$ & $\begin{array}{l}1155.7 \pm 912.8 \text { vs } \\
1071.5 \pm 751.0, P=0.523\end{array}$ & $\begin{array}{l}1329.4 \pm 1043.9 \text { vs } \\
1049.4 \pm 733.5, \mathrm{P}=0.075\end{array}$ \\
\hline DHEAS $(\mu \mathrm{mol} / \mathrm{L})(\mathrm{n}=197)$ & $\begin{array}{l}1294.4 \pm 1216.8 \text { vs } \\
1821.5 \pm 1463.0, \mathrm{P}=0.009\end{array}$ & $\begin{array}{l}1932.9 \pm 1601.0 \text { vs } \\
1578.6 \pm 1365.8, \mathrm{P}=0.262\end{array}$ & $\begin{array}{l}1276.3 \pm 1026.8 \text { vs } \\
1798.3 \pm 1526.0, \mathrm{P}=0.0121\end{array}$ & $\begin{array}{l}627.2 \pm 329.2 \text { vs } \\
1937.4 \pm 1435.3, \mathrm{P}<0.0001\end{array}$ & $\begin{array}{l}1533.1 \pm 1235.4 \text { vs } \\
1633.4 \pm 1423.4, \mathrm{P}=0.718\end{array}$ \\
\hline LNSC $(\mathrm{nmol} / \mathrm{L})(\mathrm{n}=197)$ & $\begin{array}{l}5.0 \pm 4.8 \text { vs } 3.3 \pm 3.9 \\
\mathrm{p}=0.009\end{array}$ & $\begin{array}{l}147.9 \pm 141.3 \text { vs } \\
104.7 \pm 115.5, P=0.109\end{array}$ & $\begin{array}{l}118.0 \pm 118.6 \text { vs } \\
105.1 \pm 119.3, \mathrm{P}=0.471\end{array}$ & $\begin{array}{l}113.4 \pm 146.2 \text { vs } \\
108.3 \pm 109.3, P=0.797\end{array}$ & $\begin{array}{l}330.0 \pm 176.2 \text { vs } 70.0 \pm 30.5 \\
\mathrm{P}<0.0001\end{array}$ \\
\hline Tumor size $(\mathrm{mm})(\mathrm{n}=197)$ & $\begin{array}{l}137.3 \pm 131.7 \text { vs } 92.1 \pm 107.1 \\
\mathrm{p}<0.0001\end{array}$ & $\begin{array}{l}24.2 \pm 14.5 \text { vs } 22.0 \pm 10.0 \\
\mathrm{P}=0.478\end{array}$ & $\begin{array}{l}25.0 \pm 10.8 \text { vs } 20.6 \pm 10.1 \\
\mathrm{P}=0.021\end{array}$ & $\begin{array}{l}24.8 \pm 10.6 \text { vs } 21.3 \pm 10.4 \\
\mathrm{P}=0.094\end{array}$ & $\begin{array}{l}25.4 \pm 11.5 \text { vs } 21.7 \pm 10.3 \\
\mathrm{P}=0.170\end{array}$ \\
\hline Bilaterality $(\mathrm{n}=197)$ & OR 4.3[2.2-8.1], $\mathrm{P}<0.001$ & OR 2.6[1.1-6.5], $\mathrm{P}=0.036$ & OR $2.5[1.3-4.6], \mathrm{P}=0.005$ & OR 0.8 [0.4-1.7], $\mathrm{P}=0.616$ & OR 2.0[0.9-4.5], $\mathrm{P}=0.091$ \\
\hline $\begin{array}{l}\text { Tumor rich in lipidic content } \\
(\mathrm{n}=155)\end{array}$ & OR $1.6[0.6-4.2], \mathrm{P}=0.303$ & OR 0.4 [0.1-1.1], $\mathrm{P}=0.101$ & OR $1.7[0.6-4.7], P=0.267$ & OR $0.7[0.3-1.7], P=0.423$ & OR $0.4[0.1-1.0] \mathrm{P}=0.060$ \\
\hline
\end{tabular}

Table 4. Baseline features and association of ACS-diagnostic tests with the diagnosis of comorbidities potentially related to ACS. Differences in quantitative variables are expressed in mean differences (d) between ACS and NFAI group, and for qualitative variables differences are expressed in odds ratios (OR) and 95\% confident interval (in brackets). ACS autonomous cortisol secretion, DST dexamethasone suppression test, DHEAS dehydroepiandrosterone sulphate, NFAI non-functioning adrenal incidentalomas, LNSC late-night salivary cortisol, UFC urinary-free cortisol.

contraceptives or other drugs known to alter dexamethasone metabolism, alcoholism, and psychiatric illness, some of these conditions might have not been registered in the medical records, and dexamethasone levels were not routinely evaluated during the DST ${ }^{31}$. Furthermore, other factors could also lead to false positive results in the DST ${ }^{32}$. Added to this is the known variability between techniques and assay kits for cortisol assays ${ }^{33}$ and intra-assay variability in measurements which increases in the range of low cortisol levels. Furthermore, in our institution UFC and LNSC are measured by immunochemiluminescence, which are substandard compared with the liquid chromatography/tandem mass assays recommended nowadays ${ }^{34}$. This limitation is supported by the results of a recent study ${ }^{35}$ that demonstrated that with the use of liquid chromatography/tandem mass assays, low DHEA-S levels were associated with diabetes, an association that was lost when DHEA-S was measured by immunochemiluminescence. Future studies are needed to identify more reliable and accurate markers of cortisol 


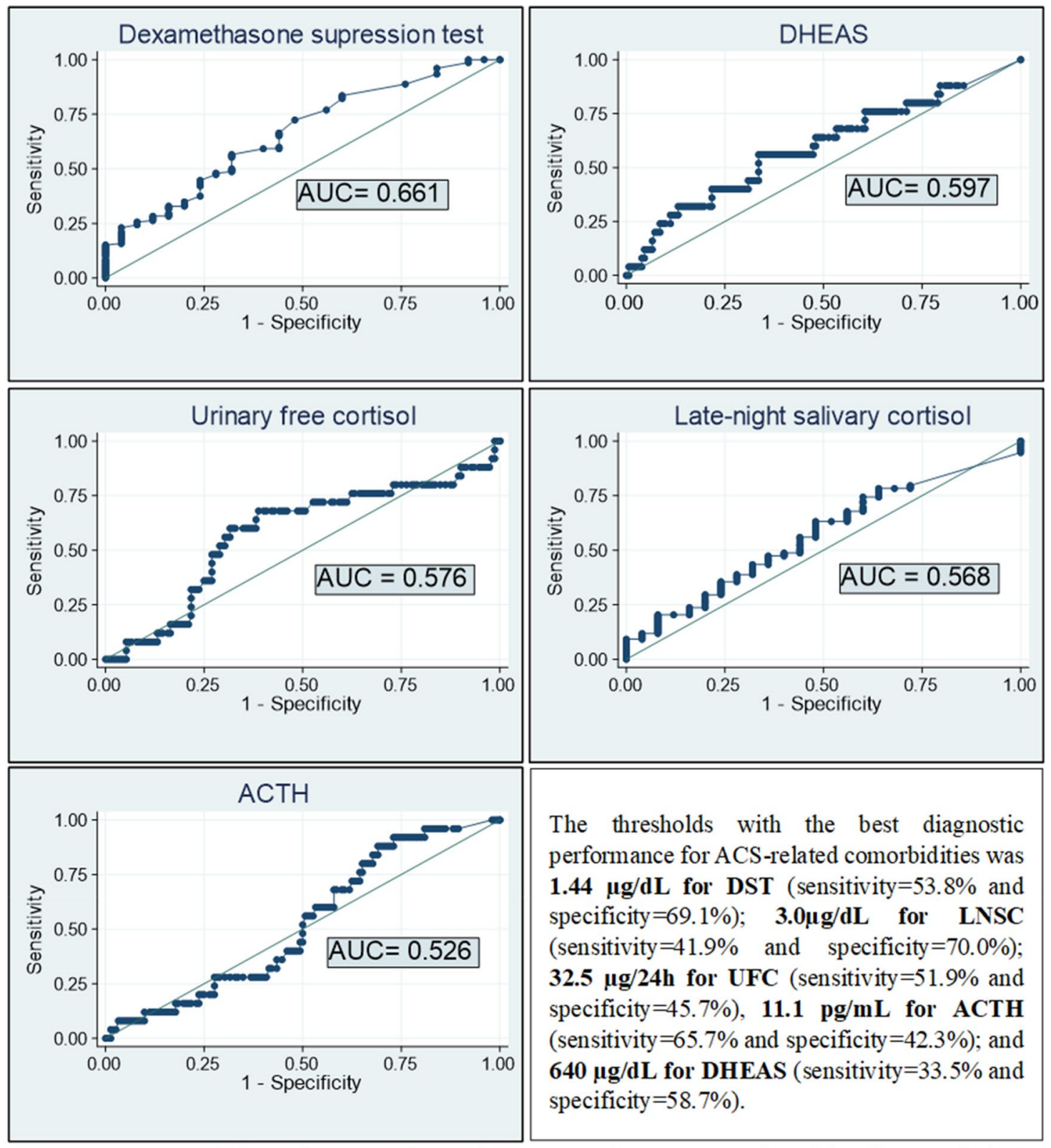

$\mathrm{ACS}=$ autonomous cortisol secretion; $\mathrm{DST}=$ dexamethasone suppresi on test $\mathrm{LNSC}=$ late-night salivary cortisol; UFC= urinary free cortisol

Figure 4. ROC curve of the different tests for the diagnosis of any comorbidities potentially related to ACS.

autonomy. In this regard, urine metabolomics ${ }^{34}$ and functional imaging studies such as adrenal iodomethylnorcholesterol scintigraphy hold promise.

\section{Conclusion}

LNSC is the one test with the highest diagnosis accuracy for ACS identification when a positive DST is used as the gold standard for ACS diagnosis. Comorbidities potentially related to ACS cannot be predicted by any single test of adrenal function possibly translating their multifactorial nature. In fact, the association of the tests evaluated here with comorbidities potentially related to ACS was poor. As a single test, DST, had the strongest association with comorbidities potentially related to ACS. Patients with elevated DST results and elevated LNSC levels had the highest cardiometabolic risk in our cohort. 


\begin{tabular}{|c|c|c|c|c|c|c|c|}
\hline & $\begin{array}{l}\text { DST }>50 \mathrm{nmol} / \mathrm{L}+\mathrm{LNSC} \\
>149 \mathrm{nmol} / \mathrm{L}(19 \mathrm{vs} .178)\end{array}$ & $\begin{array}{l}\mathrm{DST}>50 \mathrm{nmol} / \mathrm{L}+\mathrm{ACTH} \\
<2 \mathrm{pmol} / \mathrm{L}(37 \mathrm{vs.} 160)\end{array}$ & $\begin{array}{l}\mathrm{DST}>50 \mathrm{nmol} / \mathrm{L}+\mathrm{UFC} \\
>1931 \mathrm{nmol} / \mathrm{L}(12 \text { vs. } 185)\end{array}$ & $\begin{array}{l}\text { DST }>50 \mathrm{nmol} / \mathrm{L}+\text { low } \\
\text { DHEAS (23 vs. 174) }\end{array}$ & $\begin{array}{l}\mathrm{LNSC}>149 \mathrm{nmol} / \mathrm{L}+\mathrm{ACTH} \\
<2 \mathrm{pmol} / \mathrm{L}(12 \mathrm{vs} .185)\end{array}$ & $\begin{array}{l}\text { LNSC }>149 \mathrm{nmol} / \mathrm{L}+\text { UFC } \\
>1931 \mathrm{nmol} / \mathrm{L}(6 \mathrm{vs} .191)\end{array}$ & $\begin{array}{l}\text { LNSC> } 149 \text { nmol/L }+ \\
\text { low DHEAS (8 vs. 189) }\end{array}$ \\
\hline $\begin{array}{l}\text { Comor- } \\
\text { bidities } \\
\text { potentially } \\
\text { related } \\
\text { to ACS } \\
\text { (any) }\end{array}$ & OR 1.0 & $\begin{array}{l}\text { OR 6.9, 95\% CI 0.9-53.0, } \\
\mathrm{P}=0.013\end{array}$ & OR 1.0 & $\begin{array}{l}\text { OR 3.8, 95\% CI 0.5-30.0, } \\
\mathrm{P}=0.121\end{array}$ & OR 1.0 & OR 1.0 & OR 1.0 \\
\hline $\begin{array}{l}\text { Hyperten- } \\
\text { sion }\end{array}$ & $\begin{array}{l}\text { OR 7.1, 95\% CI 1.6-31.6, } \\
\mathrm{P}=0.0015\end{array}$ & $\begin{array}{l}\text { OR } 1.9,95 \% \text { CI } 0.9-4.2, \\
\mathrm{P}=0.085\end{array}$ & $\begin{array}{l}\text { OR } 8.8,95 \% \text { CI 1.1-69.2, } \\
\mathrm{P}=0.007\end{array}$ & $\begin{array}{l}\text { OR } 1.8,95 \% \text { CI } 0.7-4.5 \\
\mathrm{P}=0.219\end{array}$ & $\begin{array}{l}\text { OR } 2.3,95 \% \text { CI } 0.6-8.7 \\
\mathrm{P}=0.202\end{array}$ & $\begin{array}{l}\text { OR } 3.8,95 \% \text { CI } 0.4-32.8 \\
\mathrm{P}=0.175\end{array}$ & $\begin{array}{l}\text { OR 5.4., } 95 \% \text { CI } 0.6-44.5 \text {, } \\
\mathrm{P}=0.062\end{array}$ \\
\hline $\begin{array}{l}\text { Type } 2 \\
\text { diabetes }\end{array}$ & $\begin{array}{l}\text { OR } 0.6,95 \% \text { CI } 0.2-2.5 \\
\mathrm{P}=0.455\end{array}$ & $\begin{array}{l}\text { OR 1.6, 95\% CI 0.7-3.6, } \\
\mathrm{P}=0.243\end{array}$ & OR $1.2,95 \%$ CI $0.3-4.5$ & $\begin{array}{l}\text { OR 1.6, 95\% CI 0.6-4.2, } \\
\mathrm{P}=0.337\end{array}$ & $\begin{array}{l}\text { OR } 1.2,95 \% \text { CI } 0.3-4.5, \\
P=0.821\end{array}$ & $\begin{array}{l}\text { OR } 0.7,95 \% \text { CI 0.1-6.1, } \\
\mathrm{P}=0.726\end{array}$ & OR 1.0 \\
\hline $\begin{array}{l}\text { Dyslipi- } \\
\text { daemia }\end{array}$ & $\begin{array}{l}\text { OR } 1.5,95 \% \text { CI } 0.6-3.8 \\
P=0.427\end{array}$ & $\begin{array}{l}\text { OR } 1.3,95 \% \text { CI } 0.6-2.6, \\
P=0.516\end{array}$ & OR $1.2,95 \%$ CI $0.5-4.8$ & $\begin{array}{l}\text { OR } 2.6,95 \% \text { CI } 1.0-6.7 \\
\mathrm{P}=0.036\end{array}$ & $\begin{array}{l}\text { OR } 1.5,95 \% \text { CI } 0.5-4.8, \\
P=0.515\end{array}$ & $\begin{array}{l}\text { OR } 1.0,95 \% \text { CI } 0.2-5.2, \\
\mathrm{P}=0.970\end{array}$ & $\begin{array}{l}\text { OR } 1.8,95 \% \text { CI } 0.4-7.6, \\
P=0.442\end{array}$ \\
\hline Obesity & $\begin{array}{l}\text { OR } 0.4,95 \% \text { CI } 0.1-1.4 \\
P=0.111\end{array}$ & $\begin{array}{l}\text { OR } 1.3,95 \% \text { CI } 0.6-2.7 \\
\mathrm{P}=0.546\end{array}$ & $\begin{array}{l}\text { OR 1.1, 95\% CI 0.3-3.9, } \\
\mathrm{P}=0.856\end{array}$ & $\begin{array}{l}\text { OR } 0.8,95 \% \text { CI } 0.3-2.0 \\
\mathrm{P}=0.585\end{array}$ & $\begin{array}{l}\text { OR } 0.4,95 \% \text { CI } 0.1-2.0, \\
P=0.243\end{array}$ & $\begin{array}{l}\text { OR } 2.3,95 \% \text { CI } 0.5-11.7 \\
\mathrm{P}=0.324\end{array}$ & $\begin{array}{l}\text { OR } 0.3,95 \% \text { CI } 0.0-2.6 \\
P=0.212\end{array}$ \\
\hline $\begin{array}{l}\text { Cardio- } \\
\text { vascular } \\
\text { events }\end{array}$ & $\begin{array}{l}\text { OR 3.6, 95\% CI 1.2-11.3, } \\
\mathrm{P}=0.041\end{array}$ & $\begin{array}{l}\text { OR } 1.9,95 \% \text { CI } 0.7-5.2, \\
P=0.247\end{array}$ & $\begin{array}{l}\text { OR } 0.8,95 \% \mathrm{CI}=0.1-6.1, \\
\mathrm{P}=0.781\end{array}$ & $\begin{array}{l}\text { OR } 1.9,95 \% \text { CI } 0.6-6.4, \\
P=0.297\end{array}$ & $\begin{array}{l}\text { OR } 1.7,95 \% \text { CI } 0.4-8.6 \\
\mathrm{P}=0.514\end{array}$ & OR 1.0 & $\begin{array}{l}\text { OR } 3.0,95 \% \text { CI } 0.6-15.8, \\
P=0.239\end{array}$ \\
\hline $\begin{array}{l}\text { Cerebro- } \\
\text { vascular } \\
\text { events }\end{array}$ & OR 1.0 & $\begin{array}{l}\text { OR 4.4, 95\% CI 0.3-72.2, } \\
\mathrm{P}=0.317\end{array}$ & OR 1.0 & OR 1.0 & OR 1.0 & OR 1.0 & OR 1.0 \\
\hline
\end{tabular}

Table 5. Association of the different combined tests with cardiometabolic comorbidities at presentation. ACS autonomous cortisol secretion, DST dexamethasone suppression test, DHEAS dehydroepiandrosterone sulphate, LNSC late-night salivary cortisol, UFC urinary-free cortisol. Differences in quantitative variables are expressed in mean differences (d) between ACS and NFAI group, and for qualitative variables differences are expressed in odds ratios (OR) and 95\% confident interval (in brackets).

Received: 13 July 2021; Accepted: 5 October 2021

Published online: 15 October 2021

\section{References}

1. Wagner, J. \& Aron, D. C. Incidentalomas-A "disease" of modern imaging technology. Best Pract Res. Clin. Endocrinol. Metab. 26(1), 3-8. https://doi.org/10.1016/j.beem.2011.08.006 (2012).

2. Fassnacht, M. et al. Management of adrenal incidentalomas: European Society of Endocrinology Clinical Practice Guideline in collaboration with the European Network for the Study of Adrenal Tumors. Eur. J. Endocrinol. 175(2), G1-G34. https://doi.org/ 10.1530/EJE-16-0467 (2016).

3. Kloos, R. T., Gross, M. D., Francis, I. R., Korobkin, M. \& Shapiro, B. Incidentally discovered adrenal masses. Endocr. Rev. 16(4), 460-484. https://doi.org/10.1210/edrv-16-4-460 (1995).

4. Araujo-Castro, M. et al. Practical guide on the initial evaluation, follow-up, and treatment of adrenal incidentalomas Adrenal Diseases Group of the Spanish Society of Endocrinology and Nutrition. Endocrinol. Diabetes Nutr. 67(6), 408-419. https://doi. org/10.1016/j.endinu.2020.03.002 (2020).

5. Cambos, S. \& Tabarin, A. Management of adrenal incidentalomas: Working through uncertainty. Best Pract. Res. Clin. Endocrinol. Metab. 34(3), 101427. https://doi.org/10.1016/j.beem.2020.101427 (2020).

6. Bulow, B. et al. Adrenal incidentaloma-Follow-up results from a Swedish prospective study. Eur. J. Endocrinol. 154(3), 419-423. https://doi.org/10.1530/eje.1.02110 (2006).

7. Terzolo, M. et al. AME position statement on adrenal incidentaloma. Eur. J. Endocrinol. 164(6), 851-870. https://doi.org/10.1530/ EJE-10-1147 (2011).

8. Tabarin, A. et al. Exploration and management of adrenal incidentalomas. French Society of Endocrinology Consensus. Ann. Endocrinol. 69(6), 487-500. https://doi.org/10.1016/j.ando.2008.09.003 (2008).

9. American Diabetes Association. Classification and diagnosis of diabetes: Standards of medical care in diabetes-2019. Diabetes Care 42(1), S13-S28. https://doi.org/10.2337/dc19-S002 (2019).

10. National Cholesterol Education Program (NCEP) Expert Panel on Detection, Evaluation, and Treatment of High Blood Cholesterol in Adults (Adult Treatment Panel III). Third Report of the National Cholesterol Education Program (NCEP) Expert Panel on detection, evaluation, and treatment of high blood cholesterol in adults (Adult Treatment Panel III) final report. Circulation 106(25), 3143-3421 (2002).

11. Debono, M. et al. Cortisol as a marker for increased mortality in patients with incidental adrenocortical adenomas. J. Clin. Endocrinol. Metab. 99(12), 4462-4470. https://doi.org/10.1210/jc.2014-3007 (2014).

12. Di Dalmazi, G. et al. Cardiovascular events and mortality in patients with adrenal incidentalomas that are either non-secreting or associated with intermediate phenotype or subclinical Cushing's syndrome: A 15-year retrospective study. Lancet Diabetes Endocrinol. 2(5), 396-405. https://doi.org/10.1016/S2213-8587(13)70211-0 (2014).

13. Sbardella, E. et al. Cardiovascular features of possible autonomous cortisol secretion in patients with adrenal incidentalomas. Eur. J. Endocrinol. 178(5), 501-511. https://doi.org/10.1530/EJE-17-098 (2018).

14. Morelli, V. et al. Subclinical hypercortisolism: Correlation between biochemical diagnostic criteria and clinical aspects. Clin. Endocrinol. (Oxf) 73(2), 161-166. https://doi.org/10.1111/j.1365-2265.2010.03794.x (2010).

15. Morelli, V. et al. Cardiovascular events in patients with mild autonomous cortisol secretion: Analysis with artificial neural networks. Eur. J. Endocrinol. 177(1), 73-83. https://doi.org/10.1530/EJE-17-0047 (2017).

16. Araujo-Castro, M. et al. Presurgical predictive factors of surgical remission in Cushing's disease. Study of 32 cases. Endocrinol. Diabetes Nutr. 2, S2530. https://doi.org/10.1016/j.endinu.2021.07.004 (2021).

17. Di Dalmazi, G. et al. Progressively increased patterns of subclinical cortisol hypersecretion in adrenal incidentalomas differently predict major metabolic and cardiovascular outcomes: A large cross-sectional study. Eur. J. Endocrinol. 166(4), 669-677. https:// doi.org/10.1530/EJE-11-1039 (2012).

18. Morelli, V. et al. Long-term follow-up in adrenal incidentalomas: An Italian multicenter study. J. Clin. Endocrinol. Metab. 99(3), 827-834. https://doi.org/10.1210/jc.2013-3527 (2014).

19. Rosenbaum, A. H. et al. The dexamethasone suppression test in normal control subjects: Comparison of two assays and effect of age. Am. J. Psychiatry 141(12), 1550-1555. https://doi.org/10.1176/ajp.141.12.1550 (1984). 
20. Funder, J. W. et al. Case detection, diagnosis, and treatment of patients with primary aldosteronism: An endocrine society clinical practice guideline. J. Clin. Endocrinol Metab. 93(9), 3266-3281. https://doi.org/10.1210/jc.2008-0104 (2008).

21. Sydney, G. I., Ioakim, K. J. \& Paschou, S. A. Insulin resistance and adrenal incidentalomas: A bidirectional relationship. Maturitas 121, 1-6. https://doi.org/10.1016/j.maturitas.2018.12.002 (2019).

22. Araujo-Castro, M., Sampedro Núñez, M. A. \& Marazuela, M. Autonomous cortisol secretion in adrenal incidentalomas. Endocrine 64(1), 1-13. https://doi.org/10.1007/s12020-019-01888-y (2019).

23. Yener, S., Yilmaz, H., Demir, T., Secil, M. \& Comlekci, A. DHEAS for the prediction of subclinical Cushing's syndrome: Perplexing or advantageous? Endocrine 48(2), 669-676. https://doi.org/10.1007/s12020-014-0387-7 (2015).

24. Di Dalmazi, G. et al. Steroid profiling by LC-MS/MS in nonsecreting and subclinical cortisol-secreting adrenocortical adenomas. J. Clin. Endocrinol. Metab. 100(9), 3529-3538. https://doi.org/10.1210/JC.2015-1992 (2015).

25. Stoddart, H. Low dehydroepiandrosterone sulphate: a sensitive and specific test for the detection of subclinical hypercortisolism in adrenal incidentalomas. Clin. Biochem. 54(4), 511. https://doi.org/10.1177/0004563217704738 (2017).

26. Tanabe, A. et al. Autonomy of cortisol secretion in clinically silent adrenal incidentaloma. Horm. Metab. Res. 33(7), 444-450. https://doi.org/10.1055/s-2001-16234 (2001).

27. Bencsik, Z. et al. Low dehydroepiandrosterone sulfate (DHEA-S) level is not a good predictor of hormonal activity in nonselected patients with incidentally detected adrenal tumors. J. Clin. Endocrinol. Metab. 81(5), 1726-1729. https://doi.org/10.1210/jcem. 81.5.8626824 (1996).

28. Olsen, H., Kjellbom, A., Löndahl, M. \& Lindgren, O. Suppressed ACTH is frequently unrelated to autonomous cortisol secretion in patients with adrenal incidentalomas. J. Clin. Endocrinol. Metab. 104(2), 506-512. https://doi.org/10.1210/jc.2018-01029 (2019).

29. Vieira-Correa, M. et al. Saliva versus serum cortisol to identify subclinical hypercortisolism in adrenal incidentalomas: Simplicity versus accuracy. J. Endocrinol. Investig. 42(12), 1435-1442. https://doi.org/10.1007/s40618-019-01104-8 (2019).

30. Ueland, G. et al. Simultaneous assay of cortisol and dexamethasone improved diagnostic accuracy of the dexamethasone suppression test. Eur. J. Endocrinol. 176(6), 705-713. https://doi.org/10.1530/EJE-17-0078 (2017).

31. Ceccato, F. et al. Dexamethasone measurement during low-dose suppression test for suspected hypercortisolism: Threshold development with and validation. J. Endocrinol. Investig. 43(8), 1105-1113. https://doi.org/10.1007/s40618-020-01197-6 (2020).

32. Nieman, L. K. et al. The diagnosis of cushing's syndrome: An Endocrine Society Clinical Practice Guideline. J. Clin. Endocrinol. Metab. 93(5), 1526-1540. https://doi.org/10.1210/jc.2008-0125 (2008).

33. Hawley, J. M. et al. Serum cortisol: An up-to-date assessment of routine assay performance. Clin. Chem. 62(9), 1220-1229. https:// doi.org/10.1373/clinchem.2016.255034 (2016).

34. Araujo-Castro, M., Valderrábano, P., Escobar-Morreale, H. F., Hanzu, F. A. \& Casals, G. Urine steroid profile as a new promising tool for the evaluation of adrenal tumors. Literature review. Endocrine. https://doi.org/10.1007/s12020-020-02544-6 (2020).

35. Di Dalmazi, G. et al. The steroid profile of adrenal incidentalomas: Subtyping subjects with high cardiovascular risk. J. Clin. Endocrinol. Metab. 104(11), 5519-5528. https://doi.org/10.1210/jc.2019-00365 (2019).

\section{Author contributions}

M.A.-C., H.F.E.-M. and P.V. wrote the main manuscript text. All authors reviewed the manuscript.

\section{Funding}

Ayuda a la Investigación en Endocrinología, Nutrición y Diabetes 2019, Sociedad de Endocrinología, Nutrición y Diabetes de la Comunidad de Madrid (BECA SENDIMAD de Ayuda a la Investigación en Endocrinología, Nutrición y Diabetes 2019). Convocatoria intramural de ayudas a proyectos de investigación de investigadores noveles, investigadores clínicos asociados y/o grupos emergentes del Hospital Universitario Ramón y Cajal 2019, IRYCIS.

\section{Competing interests}

The authors declare no competing interests.

\section{Additional information}

Supplementary Information The online version contains supplementary material available at https://doi.org/ 10.1038/s41598-021-00011-4.

Correspondence and requests for materials should be addressed to M.A.-C.

Reprints and permissions information is available at www.nature.com/reprints.

Publisher's note Springer Nature remains neutral with regard to jurisdictional claims in published maps and institutional affiliations.

(c) (i) Open Access This article is licensed under a Creative Commons Attribution 4.0 International cc) License, which permits use, sharing, adaptation, distribution and reproduction in any medium or format, as long as you give appropriate credit to the original author(s) and the source, provide a link to the Creative Commons licence, and indicate if changes were made. The images or other third party material in this article are included in the article's Creative Commons licence, unless indicated otherwise in a credit line to the material. If material is not included in the article's Creative Commons licence and your intended use is not permitted by statutory regulation or exceeds the permitted use, you will need to obtain permission directly from the copyright holder. To view a copy of this licence, visit http://creativecommons.org/licenses/by/4.0/.

(C) The Author(s) 2021 